\title{
APLICAÇÃO DE TÉCNICAS DE BIOTECNOLOGIA À CULTURA E MELHORAMENTO DO MARACUJAZEIRO
}

\author{
APPLICATION OF BIOTECHNOLOGICAL \\ PROCESSES TO PASSION FRUIT CULTURE
}

\author{
Daniela Macedo de Lima ${ }^{1}$ Evelise Rejane Golombieski ${ }^{2}$ Ricardo Antonio Ayub $^{3}$
}

\section{- REVISÃO BIBLIOGRÁFICA -}

\section{RESUMO}

\begin{abstract}
A tecnologia da cultura de protoplastos, células e tecidos de plantas in vitro constitui-se em uma das áreas de maior êxito na biotecnologia. No gênero Passiflora, poucas espécies têm sido utilizadas com fins biotecnológicos nos estudos de cultura de tecido. Do pouco já realizado, obteve-se sucesso na regeneração de brotos, por via indireta, a partir de calos, ou por via direta, a partir dos explantes cotiledonares, hipocotiledonares ou foliares. A regeneração in vitro é facilmente induzida em entrenós e segmentos de gavinha, com a adição de citocinina ao meio de cultivo. Recentes avanços na regeneração de protoplastos de outras frutíferas permitiram a aplicação da hibridização somática no maracujá. O uso da engenharia genética, aproveitando-se a habilidade de regeneração das plantas de $\boldsymbol{P}$. edulis $f$. flavicarpa, torna-se relevante na tentativa de reduzir a devastação imposta por certas doenças e pragas, e também na adição de outras características de importância agronômica.
\end{abstract}

Palavras-chave: Passiflora spp, Passiflora edulis f. flavicarpa, biotecnologia, micropropagação, organogênese, protoplastos, transformação.

\section{SUMMARY}

The technology of cells, protoplast and tissue culture of plants is one of the most successful biotechnological areas. In the genus Passiflora, a few species have been used with biotechnological ends on the studies concerning tissue cultures. Regeneration of shoots can be indirect, from callus, or direct, by cotiledonary, hipocotiledonary and leaf explants. It is easy to induce in vitro regeneration of internodes and axillary tendrils if cytokinin is added to the culture medium. Early advances in the regeneration of other fruit tree protoplasts have allowed the use of the somatic hybridization process in the passion fruit. Since $\boldsymbol{P}$. edulis $f$. flavicarpa has a natural regeneration ability, the application of genetic engineering techniques becomes necessary in order to reduce the infestation by some diseases or insects, and to add relevant agricultural properties to this species.

Key words: Passiflora spp, Passiflora edulis f. flavicarpa, biotechnology, micropropagation, organogenesis, protoplasts, transformation.

\section{INTRODUÇÃO}

O cultivo de células isoladas de plantas iniciou-se neste século com Haberlandt, apud TORRES \& CALDAS (1990), o qual tentou pela primeira vez demonstrar o princípio da totipotencialidade das mesmas, através do cultivo de células e tecidos somáticos de várias espécies em solução nutritiva. Stewart et $\boldsymbol{a l}$., apud KERBAUY (1997), demonstraram pela primeira vez a possibilidade da obtenção de embriões de plantas a partir de células maduras (embriogênese somática).

A compreensão dos complexos mecanismos reguladores do desenvolvimento vegetal, como um todo, teve como consequiência o desenvolvimento da biotecnologia de plantas, entendida como a utilização integrativa de processos tecnológicos e bioquímicos, empregando-se células, tecidos e órgãos de plantas, visando à geração de produtos e serviços. Paralelamente, os avanços da biotecnologia vegetal propiciaram novos conhecimentos na área de fisiologia, da genética e da biologia molecular vegetal. A família Passifloraceae

\footnotetext{
${ }^{1}$ Bióloga, Bolsista de Aperfeiçoamento CNPq, Universidade Estadual de Ponta Grossa.

${ }^{2}$ Bióloga, Bolsista de Iniciação Científica CNPq, Universidade Estadual de Ponta Grossa.

${ }^{3}$ Engenheiro Agrônomo, Doutor, Professor Adjunto, Bolsista do CNPq, Departamento de Fitotecnia, Universidade Estadual de Ponta Grossa (UEPG), Praça Santos Andrade, s/n, 84010-330, Ponta Grossa, PR. E-mail: rayub@uepg.br. Autor para correspondência. 
é constituída de 12 gêneros e acha-se largamente distribuída nos trópicos, incluindo mais de 580 espécies, das quais a grande maioria pertence ao gênero Passiflora, sendo predominantemente nativa do Brasil (Oliveira \& Ferreira apud OTONI et al., 1995b). O gênero Passiflora abriga espécies que são conhecidas com o nome de maracujá, sendo que destas, 50 a 60 espécies produzem frutos comestíveis (MARTIN \& NAKASONE, 1970) e outras têm importante valor ornamental.

O Brasil tem o maracujá amarelo ( $\boldsymbol{P}$. edulis fv. flavicarpa) como um importante representante desse gênero, com uma área plantada de aproximadamente $24.000 \mathrm{ha}$, destacando-se, desse modo, como principal produtor mundial. Passiflora edulis f. flavicarpa, denominado maracujá amarelo, é uma das espécies mais importantes do ponto de vista econômico. É uma planta lenhosa, trepadeira perene, que se fixa a suportes por meio de gavinhas. Seus frutos são valiosos por seu sabor e aroma, sendo ricos em vitamina $\mathrm{C}$ e ácido nicotínico. Lötschert \& Beese, apud D'UTRA VAZ et al. (1993), observaram que as folhas dessa planta contêm alcalóides, os quais têm efeito redutor da pressão sangüínea.

Apesar do bom desenvolvimento da cultura do maracujazeiro de norte a sul do Brasil, atualmente se têm observado vários problemas como a bacteriose, viroses e adaptações climáticas. Segundo MARASCHIN et al. (1997), o problema de maior significância para o sucesso da cultura do maracujazeiro (P. edulis) no estado do Rio Grande do Sul parece ser a inexistência de material genético que interaja adequadamente com os ambientes do Sul do país, expondo a cultura à ocorrência de geadas. $\mathrm{KOCH}$ et al. (1998) salientam a necessidade da preservação de espécies frutíferas comestíveis e nativas da Família Passifloraceae, como Passiflora actinia (maracujá amarelo nativo), da região de Curitiba, situada no Primeiro Planalto Paranaense, visando à valoração econômica da biodiversidade. Desse modo, sabendo-se que a micropropagação de $\boldsymbol{P}$. actinia é viável para a produção clonal de mudas, pretende-se produzi-las e domesticar a espécie, na tentativa de viabilizar a instalação de pomares, os quais oferecerão aos produtores condições de cultivar um material adaptado ao clima local.

Nesse contexto, existem pesquisas realizadas em espécies do gênero Passiflora (tabela 1), empregando-se diversas técnicas e meios na biotecnologia desses maracujazeiros, com a finalidade de regenerar plantas in vitro e de obter novas variedades de interesse agronômico.

A hibridização sexual interespecífica, usando germoplasma de espécies selvagens, para promover a introgressão de genes de resistência à doença e transferir características desejáveis a espécies cultivadas, foi testada no melhoramento de Passiflora (TORRES \& MARTIN, 1974). Entretanto, Payan \& Martin e Oliveira e Ferreira, apud DORNELAS \& VIEIRA (1993), observaram que híbridos interespecíficos são difíceis de produzir e têm problemas de fertilidade.

Dessa forma, a utilização e aplicação das técnicas da engenharia genética na biotecnologia do maracujazeiro é de suma importância para a agricultura, pois ela pode melhorar a qualidade e produtividade das espécies e/ou permitir a produção de compostos secundários de interesse econômico.

\section{MICROPROPAGAÇÃO}

$\mathrm{Na}$ micropropagação de plantas lenhosas é mais difícil obter a regeneração de plantas de material fisiologicamente maduro (BONGA \& VON ADERKAS, 1992; KAWATA et al., 1995), enquanto que o tecido jovem é também conveniente para o isolamento de protoplasto e seu uso em protocolos de transformação de plantas. Essa característica foi igualmente observada no caso do maracujazeiro (D'UTRA VAZ et al., 1993; MANDERS $\boldsymbol{e t}$ al., 1994; KAWATA et al., 1995). Entretanto, tecidos jovens são aproveitáveis somente por um período relativamente curto de tempo e/ou em quantidade limitada (Vaquero $\boldsymbol{e t} \boldsymbol{a l}$. apud KAWATA $\boldsymbol{e t} \boldsymbol{a l}$., 1995). MORAN ROBLES (1978) constatou que no caso do maracujá poucas espécies foram utilizadas nos estudos de cultura de tecido a partir de materiais jovens, os quais se iniciaram com a propagação vegetativa de brotos axilares de $\boldsymbol{P}$. edulis. SCORZA \& JANICK (1980) induziram o florescimento in vitro em explantes foliares, caulinares e de gavinhas em P. suberosa. A formação de brotos de discos foliares foi obtida em $\boldsymbol{P}$. alata por Desai \& Mehta, apud D'UTRA VAZ et al. (1993), e mais recentemente, Kantharajah \& Dodd, apud D'UTRA VAZ et al. (1993), descreveram a técnica de micropropagação pela cultura direta de explantes nodais de mudas de $\boldsymbol{P}$. edulis.

A microenxertia de maracujá realizada in vitro parece ser um método viável para a regeneração de plantas a partir de meristemas, podendo ainda ser aperfeiçoada pela redução da formação de calos sobre o ponto de enxertia (BIRICOLTI \& CHIARI, 1994).

\section{ORGANOGÊNESE}

A regeneração de brotos de Passiflora pode ser indireta, a partir de calos (NAKAYAMA, 1966; MORAN ROBLES, 1979; VESTRI et al., 1990), ou pode ocorrer diretamente dos explantes 
Tabela 1 - Técnicas de biotecnologia empregadas nas principais espécies de maracujazeiro (Passiflora spp).

\begin{tabular}{|c|c|c|c|c|}
\hline ESPÉCIES & TÉCNICA & EXPLANTES & MEIOS & AUTORES \\
\hline P. edulis Sims. & Micropropagação & -Segmentos foliares. & $\begin{array}{l}\text {-MS com } 0,22 \mathrm{mg} \mathrm{L}^{-1} \text { de BAP e } 0,24 \mathrm{mg} \mathrm{L}^{-1} \text { de } \\
\text { AIB } \\
\text {-Brotos primordiais: subcultivados em MS com } \\
2,25 \mathrm{mg} \mathrm{L}^{-1} \text { de BAP e transferidos para MS } \\
\text { contendo BAP e AIB, com pH } 5,7 \text { ou } 5,8 \\
\text {-Brotos regenerados: MS fresco }\end{array}$ & $\begin{array}{l}\text { KAWATA et al., } \\
\text { (1995). }\end{array}$ \\
\hline P. edulis f. flavicarpa. & Micropropagação & $\begin{array}{l}\text {-Secções da parte central do } \\
\text { hipocótilo. } \\
\text {-Secções foliares obtidas das } \\
\text { quatro últimas folhas formadas, } \\
\text { desprovidas de bordos, zona } \\
\text { distal e proximal do limbo. }\end{array}$ & $\begin{array}{l}\text {-MS com omissão de amônia ou nitrato, com a } \\
\text { adição de tiosulfato de prata. }\end{array}$ & $\begin{array}{l}\text { FARIA \& SEGURA, } \\
\text { (1997). }\end{array}$ \\
\hline P. actinia & Micropropagação & -Foliares & $\begin{array}{l}\text {-Plântulas: MS suplementado com } 1,0 \mathrm{mg} \mathrm{L}^{-1} \text { de } \\
\text { BAP, } 0,01 \mathrm{mg} \mathrm{L}^{-1} \text { de AIB e ambos reguladores } \\
\text { (auxina e citocinina). }\end{array}$ & $\begin{array}{l}\text { KOCH, et al., } \\
\text { (1998). }\end{array}$ \\
\hline P. edulis f. edulis. & $\begin{array}{l}\text { Cultura de } \\
\text { meristema }\end{array}$ & $\begin{array}{l}\text {-Meristema com não mais que } \\
\text { quatro folhas primordiais }(0,2 \text { - } \\
0,4 \text { mm comp.). }\end{array}$ & $\begin{array}{l}\text {-MS contendo } 1,0 \mathrm{mg} \mathrm{L}^{-1} \text { de } \mathrm{BAP}, 0,5 \mathrm{mg} \mathrm{L}^{-1} \text { de } \\
\text { AIB e } 0,25 \mathrm{mg} \mathrm{L}^{-1} \text { de } \mathrm{GA}_{3} \text { (ácido giberélico). } \\
\text {-Microenxertos: sementes germinadas foram } \\
\text { transplantadas para meio MS } 1 / 2 \text {. As mudas } \\
\text { microenxertadas foram transferidas para MS } 1 / 2 \text {. }\end{array}$ & $\begin{array}{l}\text { BIRICOLTI } \\
\text { CHIARI (1994). }\end{array}$ \\
\hline $\begin{array}{l}P . \quad \text { cincinnata, } \\
\text { amethystina e } \\
\text { edulis. }\end{array}$ & Organogênese & $\begin{array}{l}\text {-Cotiledonares } \\
\text { rudimentares). }\end{array}$ & $\begin{array}{l}\text {-Regeneração: meio MS (Murashige \& Skoog) } \\
\text { contendo 1,5\% de sacarose, } 0,8 \% \text { de ágar e } 2,0 \mathrm{mg} \\
\mathrm{L}^{-1} \text { BAP de BAP (6-benzilaminopurina) } \\
\text {-Enraizamento: MS } 1 / 2\end{array}$ & $\begin{array}{l}\text { DORNELAS } \quad \& \\
\text { VIEIRA (1993). }\end{array}$ \\
\hline $\begin{array}{l}P \text {. } \text { edulis f. flavicarpa } \\
\text { Deg.; } \boldsymbol{P} \text {. mollissima } \boldsymbol{P} \text {. } \\
\text { giberti; P. maliformis; } \\
\text { P. amethystina. }\end{array}$ & Organogênese & $\begin{array}{l}\text {-Foliares - discos de "leaflets" } \\
\text { do segundo e terceiro par de } \\
\text { folhas em duas metades, } \\
\text { mantendo a nervura central. } \\
\text {-Ápices caulinares. } \\
\text {-Cotiledonares } \\
\text { hipocotiledonares. }\end{array}$ & $\begin{array}{l}\text {-MS contendo 1,0mg } \mathrm{L}^{-1} \text { de ANA (ácido } \\
\text { naftalenoacético) } \\
\text {-Ápices caulinares: MS } 1 / 2\end{array}$ & $\begin{array}{l}\text { DORNELAS \& } \\
\text { VIEIRA (1994). }\end{array}$ \\
\hline P. edulis f. flavicarpa & Organogênese & $\begin{array}{l}\text {-Porções apicais de plântulas } \\
\text { (entre } 1^{0} \text { e o } 3^{0} \text { nó). }\end{array}$ & -MS contendo $1,0 \mathrm{mg} \mathrm{L}^{-1}$ de BAP & $\begin{array}{l}\text { BIASI } \quad(1997 \\
\text { Informe verbal). }\end{array}$ \\
\hline $\begin{array}{l}\text { P. incarnata e } P \text {. edulis } \\
\text { f. flavicarpa. }\end{array}$ & $\begin{array}{l}\text { Hibridização } \\
\text { somática }\end{array}$ & $\begin{array}{l}\text {-Folhas novas recém- } \\
\text { expandidas, obtidas de plântulas } \\
\text { (com } 14 \text { a } 60 \text { dias), previamente } \\
\text { à emissão de gavinhas. }\end{array}$ & $\begin{array}{l}\text {-Isolamento de protoplastos: MS contendo } 2,5 \mathrm{mg} \\
\mathrm{L}^{-1} \text { de ANA e } 0,25 \mathrm{mg} \mathrm{L}^{-1} \text { de BAP. } \\
\text {-Regeneração de brotos: calos cultivados em MS } \\
\text { com } 1,0 \mathrm{mg} \mathrm{L}^{-1} \text { de zeatina alternado com MS } \\
\text { contendo ANA }\left(0,01 \mathrm{mg} \mathrm{L}^{-1}\right) \text { e BAP }\left(1,0 \mathrm{mg} \mathrm{L}^{-1}\right) \text {. } \\
\text { Os brotos regenerados foram subcultivados } \\
\text { alternando entre o MS solidificado com ágar e com } \\
1,0 \mathrm{mg} \mathrm{L}^{-1} \text { de zeatina e meio MS. Enraizaram em } \\
\text { MS } 1 / 2 \text { com } 1,0 \mathrm{mg} \mathrm{L}^{-1} \text { de ANA, e após } \\
\text { transferidos para meio MS. }\end{array}$ & $\begin{array}{l}\text { OTONI et al., (1995 } \\
\text { a). }\end{array}$ \\
\hline $\begin{array}{l}\text { P. edulis f. flavicarpa } \\
\text { Degener. }\end{array}$ & Protoplastos & $\begin{array}{l}\text {-Folhas novas obtidas de } \\
\text { plântulas (com } 30 \text { a } 60 \text { dias), } \\
\text { previamente à emissão de } \\
\text { gavinhas. }\end{array}$ & $\begin{array}{l}\text {-MS suplementado com } 5,0 \mathrm{mg} \mathrm{L}^{-1} \text { de ANA e } \\
0,25 \mathrm{mg} \mathrm{L}^{-1} \text { de BAP. }\end{array}$ & $\begin{array}{l}\text { D'UTRA VAZ., et } \\
\text { al., (1993). }\end{array}$ \\
\hline P. coccinea Aubl. & $\begin{array}{l}\text { Regeneração de } \\
\text { protoplastos }\end{array}$ & $\begin{array}{l}\text {-Folhas novas recém- } \\
\text { expandidas, obtidas de plântulas } \\
\text { (com } 45 \text { a } 60 \text { dias), previamente } \\
\text { à emissão de gavinhas. }\end{array}$ & $\begin{array}{l}\text { - Regenerantes obtidos pelo cultivo de calos em } \\
\text { alternância entre os meios MS com } 0,001 \mathrm{mg} \mathrm{L}^{-1} \mathrm{de} \\
\text { ANA e } 1,0 \mathrm{mg} \mathrm{L}^{-1} \text { de BAP, e MS com } 1,0 \mathrm{mg} \mathrm{L}^{-1} \mathrm{de} \\
\text { zeatina, ambos com sacarose } 3 \% \text { e ágar } 0,7 \% \text {. } \\
\text {-Enraizamento: MS } 1 / 2 \text {, com sacarose a } 2 \% \text { e } \\
1,0 \mathrm{mg} \mathrm{L}^{-1} \text { de AIB. }\end{array}$ & $\begin{array}{l}\text { OTONI et al., (1995 } \\
\text { b). }\end{array}$ \\
\hline $\begin{array}{l}\text { P. edulis f. flavicarpa } \\
\text { Degener. }\end{array}$ & Transformação & -Foliares e caulinares. & $\begin{array}{l}\text {-MS contendo 0,99 } \mathrm{mg} \mathrm{L}^{-1} \text { de BAP } \\
\text {-Enraizamento: MS com } 3,54 \mathrm{mg} \mathrm{L}^{-1} \text { de AIB } \\
\text { (ácido indolilbutírico) e } 0,48 \mathrm{mg} \mathrm{L}^{-1} \text { de ANA }\end{array}$ & $\begin{array}{l}\text { MANDERS et al., } \\
\text { (1994). }\end{array}$ \\
\hline
\end{tabular}

Ciência Rural, v. 30, n. 2, 2000. 
cotiledonares, hipocotiledonares ou foliares (DORNELAS \& VIEIRA, 1994; KAWATA $\boldsymbol{e t} \boldsymbol{a l}$., 1995). BIASI (1997 - Informe verbal) afirma que a organogênese pode ocorrer dos dois modos.

A regeneração é facilmente induzida em entrenós e segmentos de gavinha $\boldsymbol{P}$. edulis f. flavicarpa em meio MS (MURASHIGE \& SKOOG, 1962), na presença de 6 - benzilaminopurina (BAP), e gemas assim obtidas podem ser utilizadas em seguida para multiplicação de plantas (Grattapaglia $\boldsymbol{e t}$ $\boldsymbol{a l}$., apud TORRES \& CALDAS, 1990). MORAN ROBLES (1979), demonstrou que a organogênese em segmentos internodais de Passiflora edulis foi precedida pela formação de calo, diferenciação de tecidos vasculares e de zonas de diferenciação, com um centro meristemático, caracterizado pelo acúmulo de amido.

Alguns experimentos têm sido realizados para promover um aumento na freqüência de organogênese. Nesse contexto, FARIA (1997 - Informe verbal) relata que a adição de tiosulfato de prata ao meio de cultivo incrementa a capacidade proliferativa dos explantes hipocotiledonares e foliares de $\boldsymbol{P}$. edulis f. flavicarpa.

Conforme BIASI (1997 - Informe verbal) a organogênese pode ser induzida em explantes de porções apicais de mudas, obtidas entre o primeiro e o terceiro nós, com a adição de $1,0 \mathrm{mg} \mathrm{L}^{-1}$ de BAP ao meio de cultura inicial (MS), assim como MORAN ROBLES (1979). Segundo esses autores, a diferenciação da parte aérea e radicular é controlada pelo balanço entre citocinina e auxina. Para NAKAYAMA (1966), o maior teor de citocinina é favorável à proliferação de gemas, enquanto o de auxina induz a formação de raízes. No maracujazeiro, a adição apenas de citocinina ao meio de cultura (MS) promove a resposta esperada de regeneração de gemas, provavelmente pela quantidade endógena de auxina já ser suficiente para estabelecer o equilíbrio necessário à diferenciação (MORAN ROBLES, 1979). O crescimento e enraizamento das brotações adventícias foram também obtidos pela transferência dos explantes para um novo meio de cultura sem reguladores de crescimento, cuja concentração de sais foi reduzida pela metade, proporcionando a formação de calos em $96,2 \%$ dos explantes. Isso comprova a existência do balanço endógeno de hormônios, suficiente para induzir calogênese (BIASI, 1997 - Informe verbal).

\section{CULTURA DE PROTOPLASTOS}

Para D'UTRA VAZ et al. (1993), os recentes avanços na regeneração de protoplastos de várias espécies de árvores frutíferas permitirão a aplicação da hibridização somática e a transferência direta de genes para protoplastos das mesmas, como OTONI et al. (1995a) demonstraram para $\boldsymbol{P}$. edulis f. flavicarpa.

OTONI et al. (1995b) observaram baixa frequiência de organogênese em calos derivados de protoplastos, originados de folhas novas recémexpandidas de $\boldsymbol{P}$. coccinea Aubl., obtidas a partir da germinação de sementes, o que implicou a necessidade de mais estudos visando à otimização da fase de regeneração de plantas para essa espécie.

Para DORNELAS \& VIEIRA (1993), a tecnologia de cultura de protoplastos permite a hibridização somática entre espécies selvagens e cultivadas como um método adicional para obtenção de fluxo gênico entre as espécies de Passiflora. Esses autores demonstraram que é possível regenerar plantas a partir de culturas de protoplastos destas espécies de Passiflora, já que obtiveram alta frequiência de organogênese em protoplastos isolados de cotilédones de $\boldsymbol{P}$. edulis f. flavicarpa, $\boldsymbol{P}$. amethystina e $\boldsymbol{P}$. cincinnata, o que pode ser valioso nos programas de melhoramento de novas variedades e/ou porta-enxerto do maracujá amarelo.

\section{TRANSFORMAÇÃO GENÉTICA}

A transformação genética de células somáticas é uma via de acesso para a introdução de genes agronomicamente importantes. D'UTRA VAZ et al. (1993) sugeriram que essa recente estratégia de manipulação genética pode ser realizada seguindo a regeneração a partir de protoplastos de plantas de $\boldsymbol{P}$. edulis, pois a transformação de uma ou ambas espécies parentais, anteriormente ao isolamento e fusão de protoplastos, pode facilitar o desenvolvimento de sistemas de seleção para recuperar tecidos híbridos.

Em revisão bibliográfica, MANDERS et al. (1994) citam muitos exemplos do uso de Agrobacterium na transformação genética de dicotiledôneas herbáceas, porém, para plantas lenhosas são poucos os exemplos. Como principais exemplos esses autores deram ênfase para choupo (Fillatti et al.; Pythoud et al.), noz persa (McGranahan et al.), maçã (James et al.; Lambert \& Tepfer), uva (Mullins et al.), Citrus sp (Hidaka $\boldsymbol{e t}$ al.), pêssego (Smigocki \& Hammerschlag), ameixa (Mante et al.), mamão (Fitsch et al.) e Kiwi (Uematsu et al.; Rugini et al.). Eles ainda relataram pela primeira vez a transformação e regeneração do maracujazeiro amarelo via Agrobacterium tumefaciens. Os resultados demonstraram a habilidade de transformar essa frutífera comercialmente importante. Isso foi atribuído à viabilidade de um sistema de regeneração de explan- 
tes de Passiflora edulis fv. Flavicarpa e ao fato de que os explantes foram suscetíveis à infecção por uma cepa desarmada de Agrobacterium tumefaciens.

\section{CONCLUSÃO}

As condições hoje estabelecidas para o cultivo in vitro e a transformação genética do maracujazeiro podem ser utilizadas no desenvolvimento de novos cultivares com genes de interesse agronômico, beneficiando a expansão da cultura no País.

\section{AGRADECIMENTOS}

Ao CNPq, pelo fornecimento das bolsas de Aperfeiçoamento a D. M. de LIMA e de Iniciação Científica a E. R GOLOMBIESKI.

\section{COMUNICAÇÃO PESSOAL}

BIASI, L.A. 1997. Departamento de Fitotecnia e Fitossanitarismo, Setor de Ciências Agrárias, Universidade Federal do Paraná, caixa postal 672, 80001-970, Curitiba, PR.

FARIA, J.L.C. 1997. Universidade Federal de Pelotas, Faculdade de Agronomia Eliseu Maciel, Campus Universitário, caixa postal 354, 96010-900, jfaria@ufpel.tche.br, Pelotas, RS.

\section{REFERÊNCIAS BIBLIOGRÁFICAS}

BIRICOLTI, S., CHIARI, A. Meristem culture and micrografting of Passiflora edulis f. edulis. Advances in Horticultural Science, Firenze, v.8, p.171-175, 1994.

BONGA, J.M., VON ADERKAS, P. In vitro culture of trees. Dordrecht : Kluwer, 1992.498p.

DORNELAS, M.C., VIEIRA, M.L.C. Plant regeneration from protoplast cultures of Passiflora edulis fv. flavicarpa Deg., $\boldsymbol{P}$. amethystina Mikan and $\boldsymbol{P}$. cincinnata Mast. Plant Cell Reports, Berlin, v.13, p.103-106, 1993.

DORNELAS, M.C., VIEIRA, M.L.C. Tissue culture studies on species of Passiflora. Plant Cell, Tissue and Organ Culture, Dordrecht, v.36, p.211-217, 1994.

D'UTRA VAZ, F.B., SANTOS, A.V.P. dos, MANDERS, G. et al. Plant regeneration from leaf mesophyll protoplasts of the tropical woody plant, passion fruit (Passiflora edulis fv. flavicarpa Degener): the importance of the antibiotic cefotaxime in the culture medium. Plant Cell Reports, Berlin, v.12, p.220-225, 1993.

KAWATA, K., USHIDA, C., KAWAI, F. et $\boldsymbol{a l}$. Micropropagation of passion fruit from subcultured multiple shoot primordia. Journal of Plant Physiology, Stuttgart, v.147, p.281-284, 1995

KERBAUY, G.B. Clonagem de plantas in vitro: uma realidade. Biotecnologia. Ciência e Desenvolvimento, Brasília, v.1, p.30-33, 1997.

KOCH, R.C., ZANETTE, F., BIASI, L.A. et al.
Micropropagação de maracujazeiro amarelo nativo (Passiflora actinia), Curitiba, PR, 1997. In: ENCONTRO DE BIOTECNOLOGIA APLICADA À AGROPECUÁRIA, 1, 1998, Londrina, PR. Anais... Londrina : EMBRAPA SOJA, 1998. v.1. 107 p. p.106.

MANDERS, G., OTONI, W.C., D'UTRA VAZ, F.B. et al. Transformation of passion fruit (Passiflora edulis fv. flavicarpa Degener) using Agrobacterium tumefaciens. Plant Cell Reports, Berlin, v.13, p.697-702, 1994.

MARASCHIN, S. de F., BASTIANEL, M., DORNELLES, A.L.C. Caracterização izoenzimática de espécies de maracujazeiro (Passiflora spp), Porto Alegre, RS, 1997. In: CONGRESSO NACIONAL DE GENÉTICA, 43, 1997, Goiânia, GO. Anais... Goiânia : SBG, 1997. v.20. n.3. 369p. p. 182.

MARTIN, F.W., NAKASONE, H.Y. The edible species of Passiflora. Economic Botany, Baltimore, v.24, n.3, p.333343, 1970.

MORAN ROBLES, M.J. Multiplication végétative, in vitro, des bourgeons axillaires de Passiflora edulis var. flavicarpa Degener et $\boldsymbol{P}$. mollissima Bailey. Fruits, Paris, v.33, n.10, p.693-699, 1978.

MORAN ROBLES, M.J. Potentiel morpho genétique des entrenoeuds de Passiflora edulis var. flavicarpa Degener et $\boldsymbol{P}$. molissima Bailey en culture in vitro. Turrialba, São José, v.29, n.3, p.224-228, 1979.

MURASHIGE, T., SKOOG, F. Revised medium for rapid growth and bioassays with tobacco tissue cultures. Physiologia Plantarum, Copenhagen, v.15, p.473-497, 1962.

NAKAYAMA, F. Cultivo in vitro de tejidos de Passiflora caerulea. Revista de la Facultad de Agronomía de la Universidad Nacional de La Plata, La Plata, v.42, n.1, p.6374, 1966.

OTONI, W.C., BLACKHALL, N.W., D'UTRA VAZ, F.B. $\boldsymbol{e}$ t al. Somatic hybridization of the Passiflora species, $\boldsymbol{P}$. edulis f. flavicarpa Degener and $\boldsymbol{P}$. incarnata L. Journal of Experimental Botany, Oxford, v.46, n.288, p.777-785, 1995 a.

OTONI, W.C., CASALI, V.W.D., CECON, P.R. et al. Regeneração de plantas de maracujazeiro (Passiflora coccinea Aubl.) a partir de protoplastos derivados de mesofilo. Revista Ceres, Viçosa, v.42, n.243, p.461-468, 1995 b.

SCORZA, R., JANICK, J. In vitro flowering of Passiflora suberosa L. Journal of American Society for Horticultural Science, Alexandria, v.105, n.6, p.892-897, 1980.

TORRES, A.C., CALDAS, L.S. Técnicas e aplicações da cultura de tecidos de plantas. Brasília : ABCTP, EMBRAPA, CNPH, 1990. 433p.

TORRES, R.R., MARTIN, F.W. First regeneration hybrids of edible passion fruit species. Euphytica, Wageningen, v.23, p.61-70, 1974.

VESTRI, F., SCHIFF, S., BENNICI, A. In vitro shoot regeneration in Passiflora caerulea. Acta Horticulturae, Vageningen, n.280, p.105-107, 1990. 